\title{
Paleolatitude distribution of Phanerozoic marine ooids and cements
}

\author{
BRADLEY N. OPDYKE and BRUCE H. WILKINSON \\ Department of Geological Sciences, The University of Michigan, Ann Arbor, MI 48109-1063 (U.S.A.)
}

(Received June 5, 1989; revised and accepted October 31, 1989)

\begin{abstract}
Opdyke, B. N. and Wilkinson, B. H., 1990. Paleolatitude distribution of Phanerozoic marine ooids and cements. Palaeogeogr., Palaeoclimatol., Palaeoecol., 78: 135-148.

Data on 493 Phanerozoic marine ooid and cement occurrences indicate that the dominance of calcite versus aragonite in tropical marine settings has changed in response to variation in atmospheric $\mathrm{CO}_{2}$ and/or oceanic temperature gradient. Holocene ooid and cement precipitation occurs over similar latitudes, with means centered around $24^{\circ}$ and $28^{\circ}$, respectively. Aragonite and calcite also display roughly comparable distributions, with average occurrences between $25^{\circ}$ and $28^{\circ}$. Surface seawater saturation values requisite for ooid-cement carbonate precipitation are at least $3.8\left(\Omega_{\mathrm{arg}}\right)$ for aragonite and $3.4\left(\Omega_{\mathrm{arg}}\right)$ for calcite.

Ancient ooid-cement occurrences vary in space and time, with depositional zones generally closer to the equator during continental emergence; greatest extent correlates with periods of maximum transgression. Aragonite formation is favored in more equatorial localities than calcite when cement-ooid distributions are narrow and continents are emergent. Similarity of latitude distribution of marine ooids, cement, and biogenic carbonate suggests that physicochemical processes that control levels of carbonate saturation were more important in predicating sites of limestone accumulation in Phanerozoic seas than biological processes related to net productivity of various carbonate platform communities. Continental position and tropical shelf area available for carbonate accumulation dictates the relative abundance of shallow water inorganic carbonate precipitates in space and time.
\end{abstract}

\section{Introduction}

Geologists have long used the distribution of different rock types or floral/faunal assemblages to interpret ancient climates. Even before general acceptance of plate tectonics, continental mobility was inferred from anomalous lithologic occurrences such as evaporite and/or carbonate sequences at high latitudes (e.g. Wegener, 1915; Koeppen and Wegener, 1924; DuToit, 1939). Early paleomagnetic studies also relied heavily on the coincidence of specific facies within projected paleolatitudes as support of continental reconstructions (e.g. Opdyke, 1959, 1962; Blackett, 1961; Irving and Briden, 1962; Briden and Irving,
1964). Occurrences of Paleozoic tillite are still widely used to calibrate apparent polar wander paths (e.g. Van der Voo, 1988; Scotese and Barrett, 1989), and temperature indicators such as fossil fauna and flora remain the principal evidence that Cretaceous and Eocene climates were generally warmer than at present (e.g. Bailey and Sinnott, 1915; Smiley, 1967; Douglas and Williams, 1982; Wolfe and Upchurch, 1987).

Limestone-dolostone sequences are particularly notable in this regard in that carbonate accumulation is generally thought to be favored in warm shallow seas that are far removed from sources of terrigenous clastic sediment (e.g. Milliman, 1974; Wilson, 1975; 
Leeder, 1982; Tucker, 1985). Modern platforms occur preferentially on tropical to subtropical shelves (Emery, 1968; Lees, 1975) where seawater reaches its highest saturation (Morse et al., 1980), and available data suggest that paleoplatforms exhibit a similar distribution (e.g. Briden and Irving, 1964; Parrish, 1982; Ziegler, 1984); Mesozoic-Cenozoic limestones occupy a range concentrated about the equator, but exhibit a skewed distribution that suggests primary accumulation at about $20^{\circ}$ (Fig.1).

Given this relatively narrow range, the paleolatitude distribution of cratonic limestone sequences should serve as a sensitive record of changes in those parameters that control seawater saturation, including temperature, atmospheric $\mathrm{CO}_{2}$ (e.g. Mackenzie and Pigott, 1981; Berner et al., 1983), and climate (e.g. Fisher, 1981, 1984; Sandberg, 1983, 1985; Worsley et al., 1986). Previous studies of carbonate accumulation, however, have arrived at different conclusions concerning specific details of the reliability of this record. Opdyke and Wilkinson (1989), for example, suggested that maximum expansion of shallow carbonate environments occurred during the

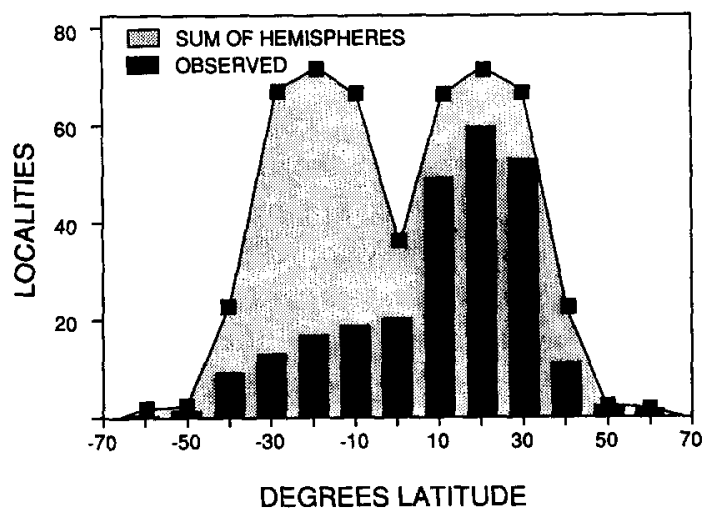

Fig.1. Paleolatitude distribution of Mesozoic-Cenozoic shallow water carbonate sequence localities, modified from Zielger et al. (1984). Bars represent actual data whereas the shaded curve represents the likely sum of northern and southern hemisphere occurrences. To eliminate bias introduced by the dominance of Mesozoic-Cenozoic shallow marine basins in the northern hemisphere, the southern hemisphere is inferred to have a similar potential for the distribution of carbonates.
Late Cretaceous, a time period characterized by continental submergence, elevated $\mathrm{CO}_{2}$, warmer climate, and possibly greater poleward extent of carbonate-saturated seawater. Briden and Irving (1964) and Ziegler et al. (1984), on the other hand, concluded that areas of carbonate deposition do not expand poleward during warmer time intervals, and suggested that limits of carbonate generation are primarily controlled by biologic factors such as the interdependence between latitude, degree of light penetration, and the direct or indirect fixation of calcium carbonate by algae in shallow platform settings.

Clearly, a number of interrelated processes act to determine areas of carbonate generation in shallow marine environments. At the coarsest scale, rates of limestone accumulation must reflect rates of delivery of $\mathrm{Ca}$ and $\mathrm{CO}_{3}^{2-}$ ions to global oceans which, in turn, depend on areas of exposed crust, rates of weathering, and amounts of hydrothermal alteration at oceanic ridges. In addition, finite ion source fluxes are partially controlled by dissolution processes in the ocean and are ultimately partitioned between deep marine and shallow platform depositional settings, depending on those factors that control net carbonate productivity of planktic and benthic marine communities. Given that planktic calcifiers only arose and diversified since the Triassic, and that a variety of taxa have dominated benthic communities over the past 590 m.y., secular change in the distribution of platform carbonate might indeed reflect a complex of biologic factors largely independent of variables such as temperature and salinity that determine levels of carbonate saturation in shallow marine settings.

In short, patterns of cratonic carbonate accumulation probably record diverse relations between biological and physicochemical processes that preclude simple correlation between limits of biogenic carbonate production, ambient seawater saturation, and climate. In order to examine these relations and to evaluate the appropriateness of carbonate sediment distribution as a record of paleo- 
climate, while striving to avoid many of the factors that influence the distribution of different biotic communities, we have evaluated Phanerozoic limits of inorganic calcium carbonate precipitation through tabulation of occurrences of marine ooids and cement. Such an approach may yield a better measure of physicochemical variation in the marine realm because these are largely abiotic precipitates, the distribution and mineralogy of which may respond to changes in physical and chemical parameters of surface seawater throughout geologic time.

\section{Abiotic carbonate precipitates}

The inorganic precipitation of calcium carbonate from marine fluids results either in the formation of layers of pore-lining cement or their centripetal counterpart as cortical laminae on ooids and other coated grains. While these forms of calcium carbonate generally record the accumulation of limestone in shallow tropical settings, variation in their abundance as sediment components, and the dominance of different calcium carbonate polymorphs among cortical-intergranular phases, may reflect regional variation in composition related to seawater carbonate saturation.

\section{Controls on formation}

Obviously, abiotic ooids and cements form in response to ambient physicochemical conditions in the surface ocean. Physically, ooid cortex growth requires elevated levels of calcium carbonate supersaturation and kinetic energy via waves or strong currents for grain agitation (e.g. Ball, 1967). Marine cement also only originates in supersaturated solutions but is most common in reefal voids where precipitation is also facilitated by strong fluid flow (e.g. Lighty, 1985).

Chemically, $\mathrm{CO}_{2}, \mathrm{pH}$, alkalinity, and ionic strength all play important roles in determining saturation state (MacIntyre, 1965; Edmond and Gieskes, 1970; Berner, 1976; Takahashi et al. 1976; Plath and Pytkowicz, 1980; Morse et al., 1980; Mucci, 1983; Cooke and Kepkay, 1984; Feely et al., 1984). but, given that calcium/ salinity ratios of modern seawater vary by no more than about $1.5 \%$ (Culkin and Cox, 1966), seawater saturation variation is largely controlled by differences in carbonate ion concentration. Because alkalinity values are relatively constant in surface oceans, change in temperature is therefore the most important factor in controlling carbonate saturation levels (e.g. Takahashi et al., 1982) and, hence, where ooids and cement originate, (Fig.2). As a result, greater carbonate saturation is found in equatorial regions as $\mathrm{CO}_{2}$ is released to the atmosphere, while in polar regions atmospheric $\mathrm{CO}_{2}$ is absorbed by the colder waters. Because of the strong dependence of carbonate saturation on temperature and hence latitude, massive carbonate precipitation from marine fluids is generally restricted to tropical seas.

Regional deviation from this pattern, however, may give rise to variation in ooid-cement distribution. Western boundary currents, for example, carry warmer water to temperature latitudes, somewhat expanding depositional range along western basin edges, while cooler

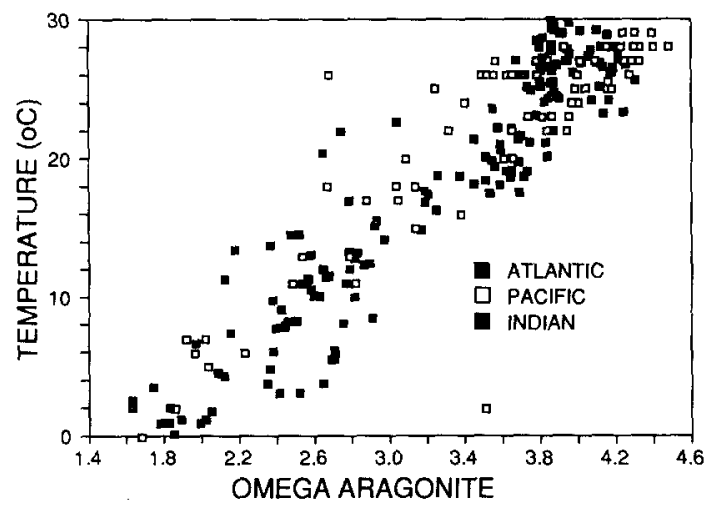

Fig.2. Relation between carbonate saturation values $\left(\Omega_{\mathrm{arg}}\right)$ and temperature for surface water of the Atlantic, Indian, and Pacific Oceans. $\Omega_{\mathrm{arg}}$ is defined as $\omega=\left[\mathrm{Ca}^{2+}\right]\left[\mathrm{CO}_{3}^{2-}\right]$ $\mathrm{K}_{\text {arg }}$ where $\mathrm{CO}_{3}^{2-}$ concentrations for surface water are taken directly from data tables in Takahashi et al. (1980, 1982). $\mathrm{Ca}^{2+}$ concentrations are assumed to vary as a function of salinity (Culkin and Cox, 1966). $\mathrm{K}_{\text {arg }}$ varies as a function of temperature and salinity (Mucci, 1983). Note a linear increase in saturation values $\left(\Omega_{\mathrm{arg}}\right)$ from polar $\left(0^{\circ} \mathrm{C}\right)$ to equatorial $\left(30^{\circ} \mathrm{C}\right)$ regions. 
currents flowing toward the equator may narrow tropical ranges along eastern margins. Similarly, excess $\mathrm{CO}_{2}$ generally occurs in areas of upwelling along narrow equatorial belts and along eastern basin margins which are regions of low temperature and low saturation state (Keeling, 1968; Takahashi and Azevedo, 1982). Where tropical currents mix with cooler high latitude water, such as along the east and west coasts of Australia, surface water $\mathrm{CO}_{2}$ is depressed relative to the atmosphere. These warm currents become undersaturated relative to atmospheric $\mathrm{CO}_{2}$ as they move to higher latitudes and slowly cool. The Antilles current, which has its origin off the northwest African coast, for example, is mature and cooling by the time it reaches the northeastern coast of the Bahamas (Takahashi et al., 1982). Here, lower $\mathrm{CO}_{2}$ and higher $\mathrm{CO}_{3}^{2-}$ concentration between $20^{\circ}$ and $30^{\circ} \mathrm{N}$ on the western Atlantic margin correlate with rapid inorganic carbonate precipitation.

Additional variation in the distribution of ooids and cement may relate to the development of enclosed and/or evaporative basins such as the Mediterranean Sea, where saturation state is higher than that of open oceans at similar latitudes. This type of deviation should be recorded as ooid/cement "outliers" from any paleolatitude distribution, much in the same manner as Mediterranean Sea occurrences are at the northern limit of a normal distribution for Holocene precipitates.

Because of such regional variations, ooids and cement are not ubiquitous in low-latitude carbonate platform-reefal environments. Among the modern areas of carbonate accumulation, only a few are significant examples of ooid generation. The Bahama Platform (e.g. Ball, 1967), Yucatan (Ward and Brady, 1973), southern Cuba (Daetwyler and Kidwell, 1959), Pedro Bank (Zans, 1958), Serrana Bank (Milliman, 1969), the Persian Gulf (e.g. Loreau and Purser, 1973), the Gulf of Suez (Sass et al., 1971), Lizard Island, Australia (Davies and Martin, 1976), and Shark Bay (Davies, 1970) are notable in this regard. Other Holocene ooid deposits include those from Baffin Bay, Texas
(Land et al., 1979), and the Mediterranean at Gabes Bay, Tunisia (Fabricius et al., 1970) and Neapolis, Greece (Richter, 1976). Ooids from Tunisia and Greece are not actively forming today, and are largely relict deposits of the Holocene transgression. Modern Indian and Pacific ocean carbonate deposits are largely void of ooids (Lees, 1975), and small deposits of ooids within areas such as the Great Barrier Reef are somewhat enigmatic (Marshall and Davies, 1975; Davies and Martin, 1976).

\section{Controls on mineralogy}

Although ooids and cement are generally restricted to warm, wave-agitated environments, either consist of magnesium calcite or aragonite, a mineralogical diversity that may also serve as a record of ocean saturation state. With increasing temperature, calcite precipitated from seawater contains greater amounts of incorporated $\mathrm{Mg}$ in the crystal lattice, ranging from only a few mole $\%$ in deep cold waters below the oceanic thermocline (e.g. Schlager and James, 1978) to nearly 20 mole \% in warm shallow settings (e.g. Alexandersson, 1972). Moreover, at tropical temperatures of $25-28^{\circ} \mathrm{C}$, the solubility of precipitated calcite with about 12 mole $\% \mathrm{Mg}$ approaches that of aragonite (Walter and Morse, 1984). Aragonite and magnesium calcite may form in intimate association as intergranular and intragranular cement, and can co-occur as alternating laminea within single ooids (Land et al., 1979; Major et al., 1988).

Both mineralogies also formed ooid-cement carbonate during much of the Phanerozoic, but exhibit considerable secular variation in their relative abundance. Whereas aragonite is presently the dominant phase as cortical carbonate within Holocene ooids, and is volumetrically nearly equal to micritic magnesian calcite as a marine cement, abiotic aragonite (or calcitized equivalent) is virtually absent from large portions of the Phanerozoic sedimentary record that correspond to periods of continental flooding (e.g. Sandberg, 1985). 
Changes in seawater $\mathrm{Mg} / \mathrm{Ca}$ ratio have been suggested as a controlling factor of calcite versus aragonite dominance (Mackenzie and Pigott, 1981). Berner (1975, 1978) has shown that higher $\mathrm{Mg} / \mathrm{Ca}$ ratio inhibits calcite growth rate, while laboratory studies by Burton (1988), Burton and Walter (1988) and Mucci et al. (1989) suggest that aragonite precipitation rate exceeds that of calcite over a wide range of $\mathrm{Mg} / \mathrm{Ca}$ and $\mathrm{SO}_{4}^{2-}$ concentrations in seawater or seawater-like solutions. When saturated with respect to both polymorphs, calcite precipitation rate increases relative to that of aragonite at low temperatures, at low $\mathrm{Mg} / \mathrm{Ca}$ ratios, and at low sulfate activities (Burton, 1988).

From a perspective of paleoclimate, aragonite versus calcite dominance in shallow carbonate sequences has also been linked to atmospheric $\mathrm{CO}_{2}$ (e.g. Sandberg, 1983) and carbonate saturation (Given and Wilkinson, 1987), with greater abundance of abiotic calcite generally recording higher sealevel, elevated $\mathrm{CO}_{2}$, and lower seawater saturation state. If correct, absence or latitude restriction of aragonite might then be considered an indication of warmer climate, as would a wider distribution of ooids and/or cement.

In order to evaluate ooid/cement distributions as records of temperature-saturation variation in Phanerozoic oceans, data on the age, geographic location, stratigraphic position, and fabric of 316 ooid and 177 cement occurrences were tabulated from the literature. Methanogenic $\left({ }^{13} \mathrm{C}\right.$-enriched) cements were not included in this compilation, nor were occurrences of ooids or cement replaced by dolomite or quartz. All of these ooid-cement occurrences are associated with relatively shallow water units, and most occur in carbonate sequences.

In the following, these data are first considered in terms of the distribution of ooids and cement, then in terms of ooid versus cement occurrences, and finally in terms of the distribution of aragonist versus calcite. Quaternary occurrences are considered first in order to establish a framework in which ancient ana- logues can be evaluated in terms of surface water saturation.

In order to reduce the effect of redundant references to a single stratigraphic unit containing marine ooids and/or cement, multiple reports of abiotic carbonate of the same age within a continuous geographical area were combined into a single "occurrence". With respect to Quaternary units, this lumping of reports results in occurrences at a scale of the Bahamas, the Persian Gulf, or Yucatan. Older Phanerozoic occurrences are mostly at the stratigraphic level of formations.

\section{Quaternary precipitates}

Latitudes of 78 Pleistocene-Holocene ooidcement occurrences are more-or-less normally distributed within the northern hemisphere (Table 1), and exhibit a mean latitude of $27^{\circ}$ (Fig.3A). Reported modern cements are much more numerous $(n=56)$ than coeval ooids $(n=22)$, and exhibit a northern hemisphere mean of $28^{\circ}$ (Fig.3B). Aragonite $(n=22)$ and calcite $(n=34)$ cement exhibit statistically indistinguishable distributions with means at $27^{\circ}$ and $28^{\circ}$, respectively. It is notable, however, that several examples of calcite cement range to $60^{\circ}$ (Fig.3B). These are somewhat anomalous among modern carbonate precipitates in that they largely comprise occurrences within terrigenous clastic sediment, and are probably only recognized as early cement phases because of their presence in otherwise

\section{TABLE I}

Latitudinal distribution of Phanerozoic ooids and cement

\begin{tabular}{|c|c|c|c|c|c|c|}
\hline & \multicolumn{3}{|c|}{ Quaternary } & \multicolumn{3}{|c|}{ Phanerozoic } \\
\hline & $n$ & $X$ & $\mathrm{SD}$ & $n$ & $X$ & SD \\
\hline Ooids and Cement & 78 & 27 & 10 & 415 & 16 & 10 \\
\hline All ooids & 22 & 24 & 8 & 294 & 16 & 10 \\
\hline Aragonite ooids & 19 & 25 & 7 & 36 & 12 & 9 \\
\hline Calcite ooids & 4 & 21 & 9 & 138 & 17 & 109 \\
\hline All cement & 56 & 28 & 12 & 121 & 16 & 10 \\
\hline Aragonite cement & 22 & 27 & 7 & 25 & 9 & 9 \\
\hline Calcite cement & 34 & 28 & 14 & 96 & 18 & 10 \\
\hline
\end{tabular}




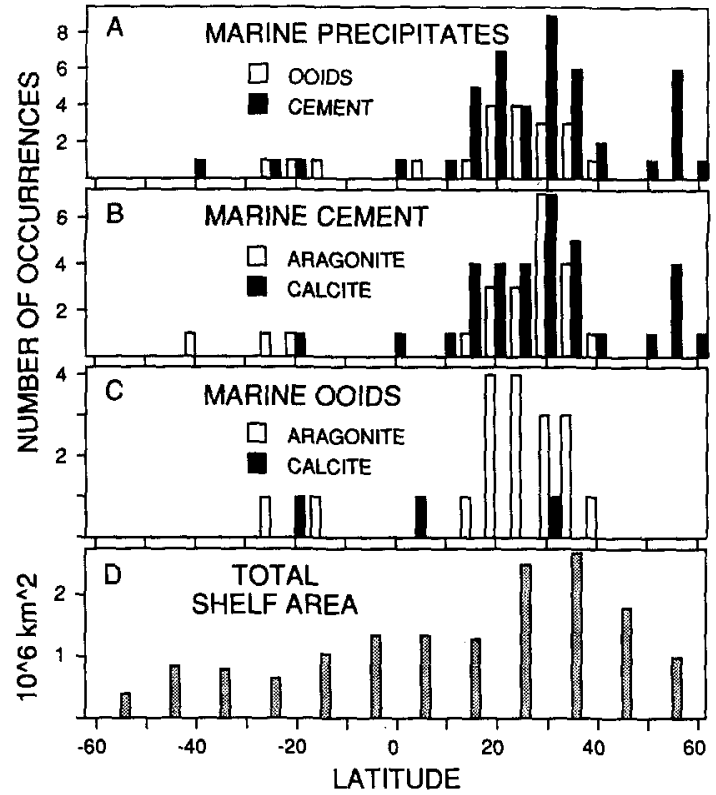

Fig.3. Latitudinal distribution of Quaternary carbonate precipitates.

A. Distribution of ooids and cement. Note similar mean occurrences at about $28^{\circ}$, but that cement is reported from a somewhat broader range.

B. Reported calcite-aragonite cement distributions which indicates aragonite has a narrower range than calcite relative to distance from the equator.

C. Quaternary ooids. Virtually all Holocene deposits are aragonite, but calcite grains are forming in Baffin Bay, Texas, and occur as several relict deposits in deeper shelf settings. Differences between total ooid occurrences in A and $\mathrm{C}$ reflects the fact some deposits include both aragonite and calcite as cortical phases. D. Late Cenozoic shelf areas from Parrish (1985). Note predominance of shallow shelf settings at about $30^{\circ} \mathrm{N}$, and a general correspondence between this pattern, that of ooid-cement distributions (Fig.3A), and that of shelf carbonate sequences (Fig.1).

unlithified units. Ancient analogues are largely unidentified in terrigenous sequences.

All Quaternary ooids occur within $40^{\circ}$ of the equator (Fig.3C) but are presently forming in only 6 locations to any significant degree. Grains in all but one of these (Baffin Bay; Land et al., 1979) are exclusively aragonite. Although the presence of calcite among three relict occurrences may reflect variation in seawater chemistry and dominant cortical mineralogy on very short time scales, the scarcity of Quaternary ooids relative to marine cement renders comparisons between aragonite and calcite statistically meaningless.

Distribution of modern (recent) marine ooids and cements suggests that carbonate precipitation closely reflects sea-surface saturation gradient, in that no occurrences within limestone sediment lie poleward of $35^{\circ}$. Quaternary ooid-cement distribution is strikingly similar to that of primarily biogenic carbonate (Fig.1); virtually all occurrences are in the northern hemisphere, the Caribbean region in particular.

Theoretically, such a skewed distribution could in part reflect warmer northern hemisphere sea surface temperatures. The intertropical convergence zone, the equatorial area where warm air rises and moves poleward, is skewed about $5^{\circ}$ to the north due to the cooling influence of Antarctica. However, climate zones are generally symmetrical on either side of the equator and average temperature is likely to be similar at both $20^{\circ} \mathrm{N}$ and $\mathrm{S}$ (Neiburger et al., 1982).

Almost certainly, the disproportionately large number of ooid and cement occurrences north of the equator merely reflects the predominance of land area presently in the northern hemisphere and, hence, the greater areal extent of shallow shelf environments in this hemisphere as well. The distribution of Quaternary ooid/cement occurrences, Mesozoic-Cenozoic platform carbonate sequences, and estimates of late Cenozoic shelf areas by latitude from Parrish (1985), all exhibit similar patterns (Fig.3D). This suggests that, while global temperature gradients and poleward extents of saturated surface waters indeed control limits of carbonate precipitation, the abundance of ooid/cement occurrences more closely reflects the areal size of agitated shallow water settings in which precipitation can occur.

\section{Phanerozoic precipitates}

In order to determine an appropriate latitude for each reported occurrence of Phanerozoic 
ooids $(n=294)$ and cement $(n=121)$ (Table 1$)$, all were plotted on appropriate paleogeographic maps by Denham and Scotese (1988). Errors in paleomagnetic data on which these reconstructions were based are about $5^{\circ}$, with uncertainties for the lower Paleozoic perhaps ranging to $10^{\circ}$ (Van der Voo, 1988).

Data on the distribution of these 415 Phanerozoic ooids and cements demonstrate that Paleozoic occurrences are dominantly in the southern hemisphere, while the majority of Mesozoic and Cenozoic localities occur north of the equator. These define a mean distribution extending from about $30^{\circ} \mathrm{S}$ in the Cambrian to about $30^{\circ} \mathrm{N}$ in the Tertiary (Fig.4). Virtually all occur within $35^{\circ}$ degrees of the equator, a band also defined by most data on Quaternary ooids and cement.

Although ancient carbonate components are now calcite and/or dolomite, original mineralogy can be inferred from preserved fabrics due to the fact that diagenetic calcitization of aragonite typically results in the obliteration of textural detail (Sandberg, 1983, 1985; Tucker, 1984; Chow and James, 1987). Ancient ooids that exhibit radial arrangement of constituent acicular crystallites are generally interpreted as having been precipitated as calcite, while sparry cortices of interlocking anhedral calcite crystallites were formerly

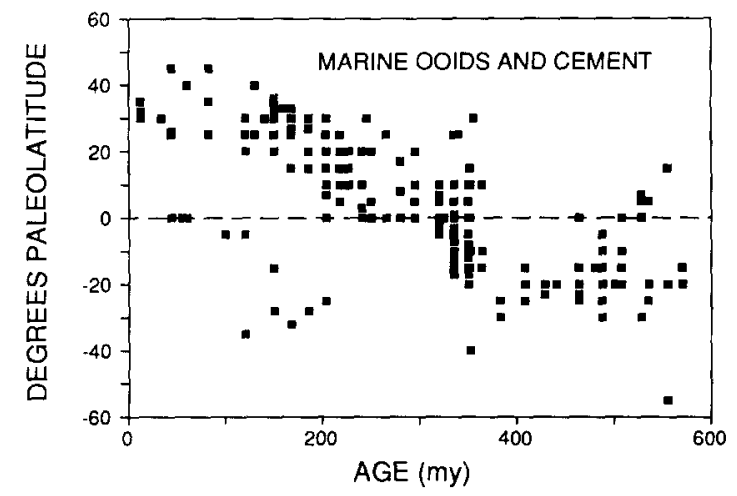

Fig.4. Paleolatitudinal distribution of Phanerozoic marine ooids and cement exclusive of Quaternary occurrences. Latitudes determined from palaeogeographic maps of (Denham and Scotese, 1986). Note a striking progressive shift in sites of carbonate precipitation from the southern to the northern hemisphere over the past 590 m.y. aragonite. Original cement mineralogy can be inferred employing similar textural criteria (e.g. James and Klappa, 1983), with botryoidal masses common to former aragonite and isopachous crusts typical or calcite.

Taken together, the distribution of ancient ooids and cement are not statistically different, with both exhibiting a mean of $16^{\circ}$ from the equator with standard deviations of about $10^{\circ}$ (Fig.5A). Former aragonite cement however, shows a narrower distribution about the equator than does calcite (Fig.5B). Differences between aragonite and calcite ooids are more subtle (Table 1), but radial calcite ooids extended to higher latitudes than did coeval grains of aragonite (Fig.5C).

\section{Discussion}

On the basis of reported aragonite-calcite marine ooids and cement, several conclusions can be drawn concerning the distribution of inorganically precipitated carbonate over the past $590 \mathrm{~m} . \mathrm{y}$. These pertain to their distribu-

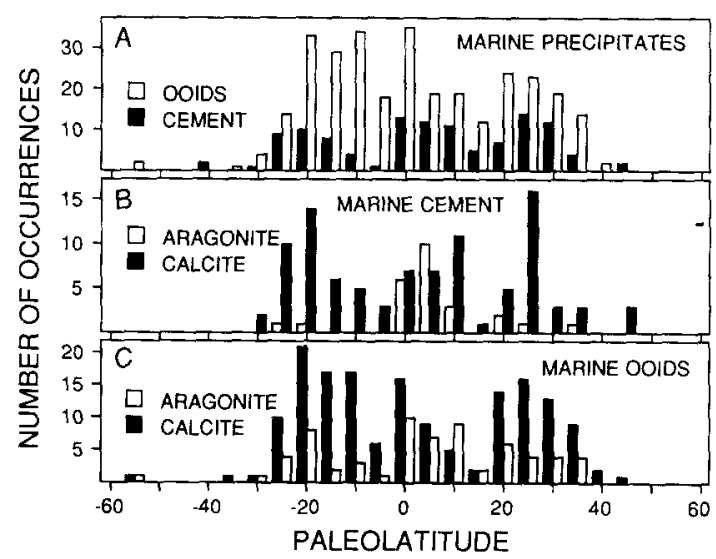

Fig.5. Paleolatitude distribution of Phanerozoic marine ooids and cement exclusive of Quaternary examples.

A. Distribution of ooid-cement occurrences. Although reports of marine oolite are much more common than those of cement, distribution of the two populations is statistically indistinguishable.

B. Latitudes of aragonite and calcite marine cement suggesting that occurrences of aragonite are generally more equatorial than those of calcite.

C. Aragonite and calcite oolite distribution. While less pronounced than cement, aragonite occurrences define a narrower latitudinal distribution than do calcitic grains. 
tion: (1) relative to saturation values in modern oceans, (2) relative to dominant allochem mineralogy, (3) relative to different component types, (4) relative to paleolatitude, (5) relative to biogenic debris that makes up most shallow marine carbonate sediment, and (6) relative to their utility as records of ocean temperature-saturation variation.

\section{Present distributions}

In order to understand those processes which control carbonate precipitation and polymorphism during cement crystal growth and/or ooid cortex accretion, preliminary data on saturation of modern surface water with respect to aragonite were compared to areas of ooid and cement formation. Surface water chemistry data from Takahashi et al. (1980, 1982) exhibit increasing saturation values $\left(\Omega_{\mathrm{arg}}\right)$ from poles to latitudes of about $20^{\circ}$, and constant or slightly decreasing $\Omega_{\text {arg }}$ from there to the equator. As a result, equatorial zones exhibit a slight saturation minima (Fig.6).

Decreased saturation at equatorial latitudes primarily reflects reduced $\mathrm{CO}_{3}^{2-}$ concentration, largely due to the higher $\mathrm{CO}_{2}$ of upwelling water (Broecker and Peng, 1984), but in

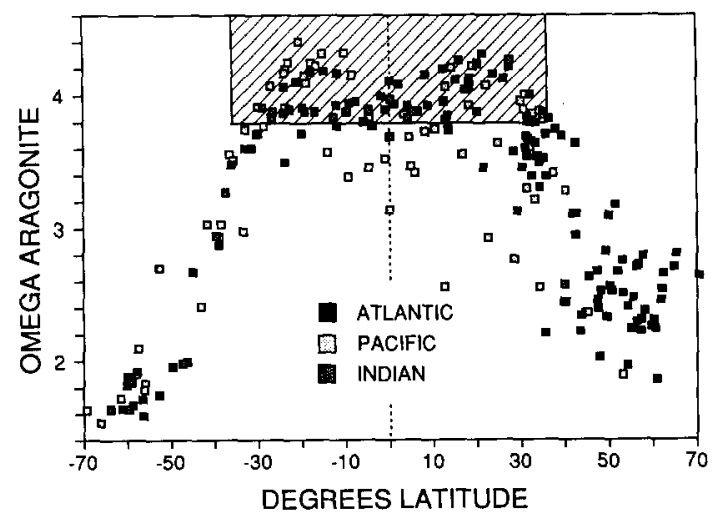

Fig.6. Relation between latitude and carbonate saturation values for surface waters of the Atlantic, Indian and Pacific Oceans. From data in Takahashi et al. $(1980,1982)$. Note an increase in $\Omega_{\text {arg }}$ values from polar to equatorial regions. Diagonally hachured box delimits the range of saturation values that correspond to the limits of aragonitic Quaternary ooids and cement. part reflecting higher rainfall and lower evaporation in these areas. As a result, surface waters of greatest saturation occur between $10^{\circ}$ and $30^{\circ}$ and include equatorial regions on the western side of basins where upwelling is weak.

Holocene cement is most abundant in these areas, but exhibits a distribution extending somewhat beyond that for ooids, both to the north and to the south. Aragonite ooids and cement most commonly form in shallow seas near open ocean water where $\Omega_{\text {arg }}$ exceeds about 3.8 and summer temperatures exceed about $25^{\circ} \mathrm{C}$ (Fig.6). In such areas, seawater $\mathrm{CO}_{2}$ is commonly $10-15 \mathrm{ppm}$ below that in equilibrium with the atmosphere (Takahashi and Azevedo, 1982). Calcite cement can form in more temperate regions, and the minimum $\Omega_{\mathrm{arg}}$ for these precipitates is about 3.4. Because calcium carbonate saturation data represent open ocean surface water, these sacuration values probably represent minima from which shallow shelf waters evolve.

\section{Aragonite-calcite distributions}

With respect to original mineralogy, aragonite ooid-cement occurrences generally have narrower ranges than coeval calcite, both in modern (Fig.3) and ancient (Fig.5) sequences. The reason for this difference probably reflects relations between phase solubility and mineralogy or Mg content. As noted above, at typical tropical marine temperatures, calcite with about $12 \mathrm{~mole} \% \mathrm{Mg}$ has a solubility roughly equivalent to that of aragonite (Walter and Morse, 1984). Moreover, available compositional data on shallow Holocene cements indicated that $\mathrm{Mg}$ content decreases from about 18 to about 9 mole $\%$ with increasing latitude. Although it is not (as yet) possible to determine original $\mathrm{Mg}$ contents for ancient cortical or cement carbonate, there is no reason to believe that Phanerozoic calcites did not exhibit a similar (or greater) range of compositions. Hence, there is no reason why calcite ooids and/or cement, including those with lower $\mathrm{Mg}$ contents, should not have 
extended over a wider latitude range than coeval aragonite.

With respect to secular variation in original mineralogy, data on ooids and cement indicate that both have changed with time (Fig.7), with aragonite dominance corresponding to periods of continental emergence (e.g. Sandberg, 1983, 1985). If change in mineralogy reflects variation in seawater carbonate saturation, then an absence of aragonite probably records periods of lower carbonate saturation in surface seawater, and perhaps lower $\mathrm{Mg} / \mathrm{Ca}$ ratios as well.

\section{Ooid-cement distributions}

Available data indicate no significant differences in the distribution of marine ooids versus cement in modern or ancient sequences, a similarity of occurrences that probably reflects the fact that both require supersaturated fluids and elevated rates of fluid flow for their formation. Although Quaternary cement exhibits a broader distribution than ooids (Fig.3), this is not true for older Phanerozoic sequences with a much larger number of occurrences (Fig.5). Modern cement predominates in reefal and grainstone voids where fluid flow is

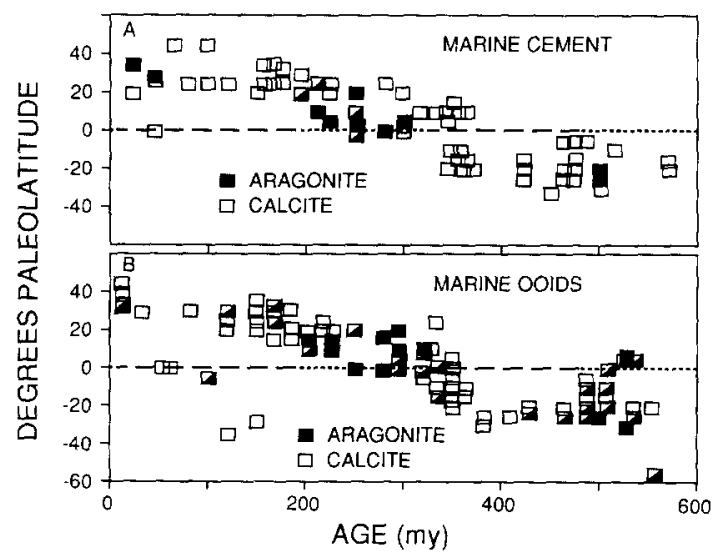

Fig.7. Paleolatitudes of ooids and cement plotted by inferred original mineralogy. Note similar aragonite dominance relative to calcite (dotted line portions) for both components during the early Paleozoic, late Paleozoic-early Mesozoic, and late Cenozoic. These correspond to periods of continental emergence. This plot does not include Quaternary data. high and/or sediment accumulation rates low, and most ooids form in shoals along non-reefal but wave-agitated shelf margins as well. The similarity of these settings is probably reflected in the equivalence of ooid-cement distributions.

\section{Biochemical-physicochemical distributions}

Perhaps more importantly, data on ooidcement distributions suggest that latitudes represented by these components are little different from those reported for platform carbonate sequences composed primarily of metazoan hardpart debris. Such a similarity strongly indicates that, at least from a standpoint of carbonate generation, biochemical and physicochemical processes operate simultaneously in largely coincident shallow marine settings. Most of these are within $35^{\circ}$ of the equator; although a few cratonic limestones formed poleward of these limits (e.g. early Tertiary bryozoan limestones of Australia) and range to $60^{\circ}$, a few Holocene marine cements occur at similar latitudes as well (e.g. Fig.3).

Conventional wisdom has long held that carbonate deposition is enhanced in low latitudes, in shallow water, and in areas farremoved from areas of significant terrigenous clastic influx (e.g. Wilson, 1975; Bathurst, 1975). Although the distribution of ooid-cement and limestone occurrences are largely in accord with these generalizations, fundamentally different mechanisms are responsible for the formation of each type of sediment component. Most limestone units consist of hardpart debris, and many individuals have therefore suggested that biological mechanisms act as the primary factors in predicating carbonate sediment generation (e.g. Ziegler et al., 1984). Correspondence between limestone accumulation and saturated seawater, on the other hand, has led others to suggest that physicochemical mechanisms are primarily responsible for determining rates of biogenic carbonate generation.

Collectively, we know little concerning the 
relative importance of biological versus physicochemical processes in the generation of carbonate sequences, even in modern shelfreefal settings, nor is it well understood what carbonate distributions and accumulation rates might be like in the absence of either now-dominant metazoan calcifiers or nowprevalent carbonate-supersaturated ambient marine fluids. If biological systems were primary causative agents of carbonate accumulation, some difference in the distribution of biotic and abiotic carbonate components might be anticipated. However, there appears to be no discernable dissimilarity in the distribution of carbonate components generated by direct precipitation versus those formed during biomineralization. This correspondence seemingly records an intimate link between seawater composition and the fundamental controls on carbonate formation, and suggests that limestone deposition will largely correspond to areas of supersaturated seawater, regardless of the dominance of various taxonomic groups in shallow marine settings.

\section{Ooid-cement distribution and climate}

Regardless of likenesses and/or differences in distributions based on mineralogy, allochem type, or mechanism of precipitation, virtually all Phanerozoic ooid-cement occurrences define a rather striking trend of increasingly northern sites of deposition over the past $\mathbf{5 1 0}$ m.y. (Fig.4). Calculation of drift tracks for seven depositional basins in Africa, Asia, Australia, Europe, Indian, North America, and South America, demonstrates that most continents have moved northward during the Phanerozoic (Fig.8). To the degree that reported marine ooid and cement occurrences reflect actual abundances in carbonate sequences, such a relation indicates an intimate relation between tropical areas of flooded continent and areas/volumes of carbonate accumulation in shallow epicratonic settings.

One immediate result of such dependence is that mean or average latitudes of accumulation should more closely reflect the average

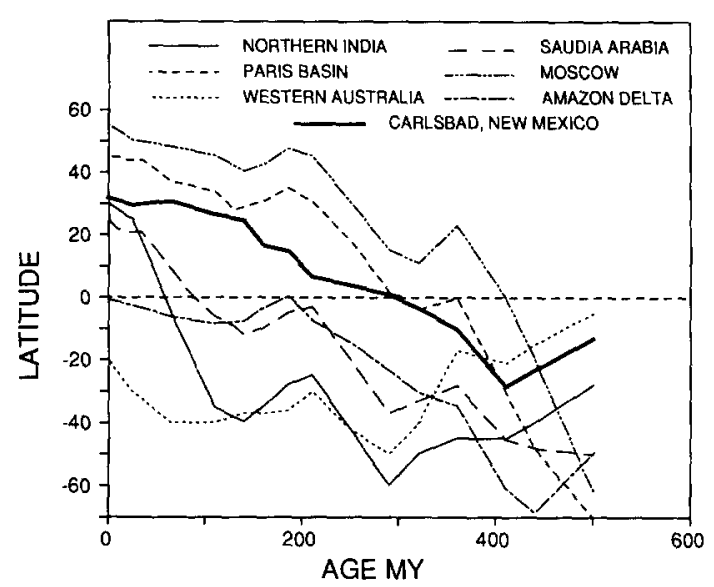

Fig.8. Cambrian to recent drift tracks for seven sedimentary basins with a global distribution (India, Europe, Australia, Saudi Arabia, Asia, South America, and North America) showing general movement of the most continents to more northern latitudes over the past $510 \mathrm{~m} . \mathrm{y}$. Note similarity between ooid-cement latitudes (Fig.4) and the drift tract for the Permian Basin, New Mexico (heavy line) (Denham and Scotese, 1988).

distribution of shallow tropical seas than any relation with seawater saturation gradient; mean latitudes of inorganic carbonate precipitates are strongly dependant on paleopositions of shallow water shelves.

Whereas virtually all reported Paleozoic ooids and cements formed south of the equator, northern hemisphere dominance began when North America, which includes $64 \%$ of tabulated data, crossed the equator during the Carboniferous (Fig.4 and 8). Such strong correlation between patterns of continental drift and patterns of ooid-cement deposition significantly limits the usefulness of average precipitate latitude as a record of change in ocean temperature and/or carbonate saturation.

What then can be said concerning ooidcement occurrences and secular change in seawater saturation? Whereas distribution averages relative to the equator are significantly biased by continental area, one other possible measure of saturation gradients is variation in the actual extent of oolite-cement occurrences. Theoretically, and all other parameters remaining constant, increasing $\mathrm{CO}_{2}$ should result in lower seawater carbonate saturation 
which, at any specified time, decreases poleward with surface temperature. Hence, aragonite dominance, cooler climate, lower sealevel, and depressed $p \mathrm{CO}_{2}$ (Berner et al., 1983; Sandberg, 1983, 1985), may be recorded as compressed limits of ooid-cement occurrences. Such a relation, of course, is dependent on the occurrence of shallow shelf depositional areas across poleward limits of carbonate precipitation in at least one hemisphere, on the preservation of marine sediment from that setting, and on the evaluation of that sequence in the ooid-cement tabulation.

Calculation of maximum Phanerozoic ooidcement latitudes yields a trend with a more restricted range during the Permo-carboniferous, a time period that corresponds to general continental emergence (Vail, 1977), and perhaps to the largest glacial epoch in Phanerozoic history (Frakes and Francis, 1988; Fig.9). Relationships such as these suggest a qualitative link between eustasy, seawater saturation, ooid-cement mineralogy, pole-to-equator temperature gradient, and the latitude range over which carbonate precipitation is likely to occur.

\section{Conclusions}

In an effort to evaluate relations between climate and shallow water carbonate distribu-

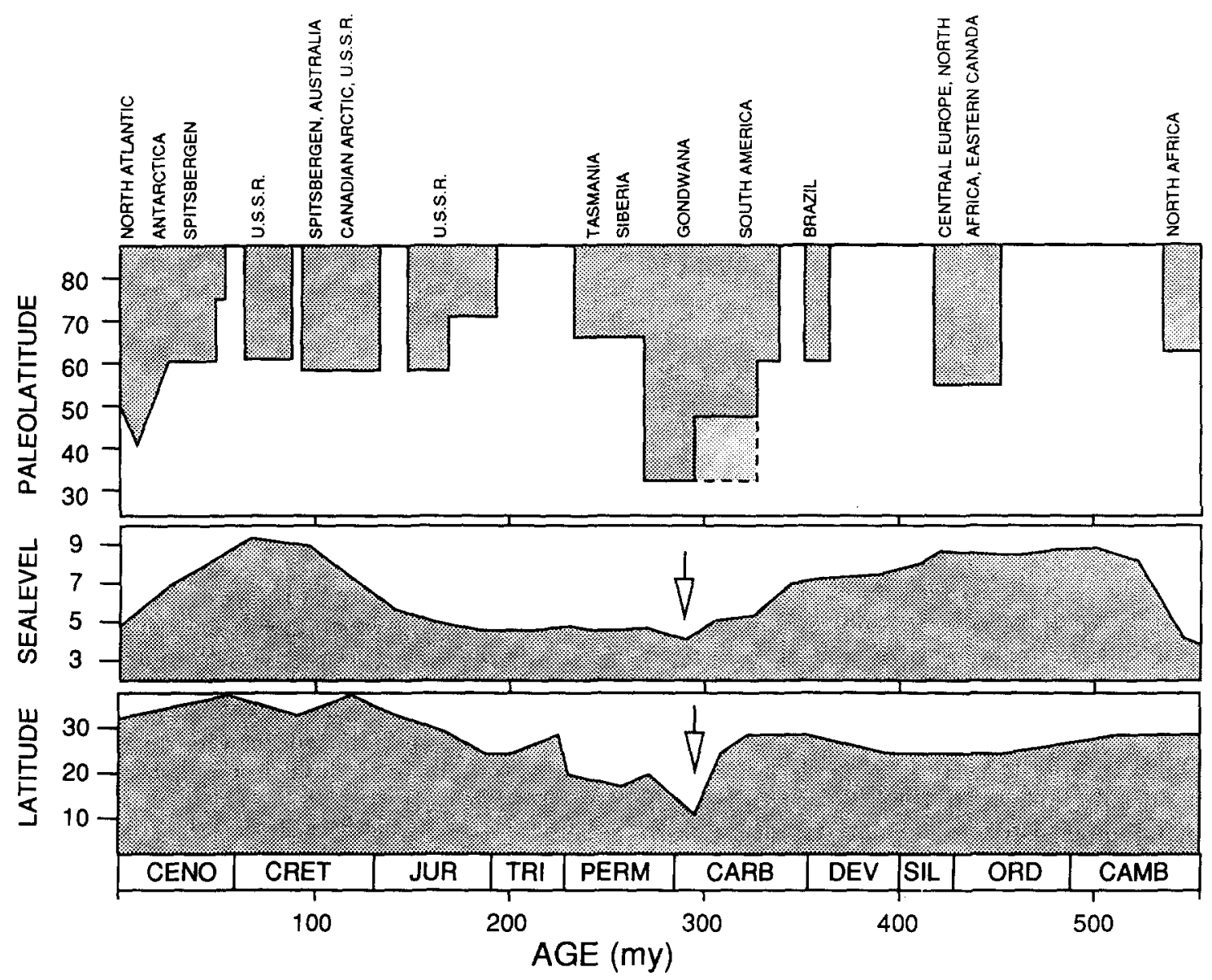

Fig.9. Extent of Phanerozoic ice-rafted debris in Phanerozoic sedimentary sequences (Frakes and Francis, 1988), estimates of global sealevel (Vail, 1977), and maximums of ooid-cement occurrences. Note general correspondence between equatorial expansion of ice-transported material, greater continental emergence, and generally narrower distribution of abiotic ooidcement precipitates from about 350 to 200 m.y. 
tion, latitude and original mineralogy of Phanerozoic ooid and cement occurrences were tabulated from 493 reports in the literature (Table 1). Mineralogical dominance of aragonite over calcite in both ooids and cement is, as pointed out by Sandberg (1983, 1985) coincident with periods of continental emergence. Mean latitudes of modern and ancient ooid and cement occurrences suggest a wider latitude range for calcite relative to aragonite, and an identical range for ooids relative to cement and oolite-cement relative to biogenic debris.

Ooid-cement formation is an inorganic processes that only occurs when critical thresholds of physical agitation and chemical saturation have been surpassed. Global ocean carbonate saturation data indicate that saturation levels $\left(\Omega_{\text {arg }}\right)$ must be at least 3.4 for calcite cement growth and 3.8 for aragonite ooidcement precipitation. Additional data on ooid shoal water compositions are necessary to more tightly constrain this value.

Finally, ooid-cement occurrence data suggest that marine carbonate systems have responded to changes in temperature and $\mathrm{CO}_{2}$ concentrations in global oceans. Carbonate precipitates have not been uniformly distributed over invariant areas of deposition. Rather, Phanerozoic ranges have evidently narrowed while calcite precipitation gave way to aragonite dominance during periods continental emergence and inferred cooler climate. This behavior implies a higher low-latitude saturation state relative to calcite seas, while at the same time surface waters between about $30^{\circ}$ and $40^{\circ}$ from the equator have lower saturation states than calcite seas. In effect, aragonite seas correspond to more highly saturated waters in lower latitudes. Calcite oceans, generally correspond to periods of continental flooding, elevated $\mathrm{CO}_{2}$ warmer temperature, lower equatorial calcium carbonate saturation state, and an expanded latitude range of ooid-cement deposition.

\section{Acknowledgments}

We thank Taro Takahashi for the kindly sending us the TTO North Atlantic data, Rob
Van der Voo for advice on the lower Paleozoic paleomagnetics, and David Dettman for reviewing early versions of the manuscript. Steve Boss and Nancy Opdyke helped with statistical manipulations of ooid-cement data. Angela DiMartino was a great help during the literature search. An anonymous reviewer helped to improve the final draft. Research on patterns of Phanerozoic carbonate accumulation at The University of Michigan is supported by the National Science Foundation, NSF grants EAR-86-07970 and EAR-88-03910.

\section{References}

Alexandersson, T., 1972. Intragranular growth of marine aragonite and $\mathrm{Mg}$-calcite - evidence of precipitation from supersaturated seawater. J. Sediment. Petrol., 42: 441-460.

Ball, M. M., 1967. Carbonate sand bodies of Florida and the Bahamas. J. Sediment. Petrol., 37: 556-591.

Bailey, I. W. and Sinnott, E. W., 1915. A botanical index of Cretaceous and Tertiary climates. Science, 41: 831-834.

Bathurst, R. G. C., 1975. Carbonate Sediments and Their Diagenesis (Developments in Sedimentology, 12). Elsevier, New York, N.Y., $658 \mathrm{pp}$.

Berner, R. A., 1975. The role of magnesium in the crystal growth of calcite and aragonite from seawater. Geochim. Cosmochim. Acta, 29: 489-504.

Berner, R. A., 1976. The solubility of calcite and aragonite in seawater at atmospheric pressure and $34.5 \%$ salinity. Am. J. Sci., 276: 713-730.

Berner, R. A., 1978. Equilibrium kinetics, and the precipitation of magnesian calcite from seawater: Am. J. Sci., 278: 1475-1477.

Berner, R. A., Lasaga, A. C. and Garrels, R. M., 1983. The carbonate-silicate geochemical cycle and its effect on atmospheric carbon dioxide over the past 100 million years. Am. J. Sci., 283: 641-683.

Blackett, P. M. S., 1961. Comparisons of ancient climate with the ancient latitude deduced from rock magnetic measurements. Proc. R. Soc. Lond., A263: 1-30.

Briden, J. C. and Irving, E., 1964. Paleolatitude spectra of sedimentary paleoclimatic indicators. In: A. E. M. Nairn (Editor), Problems in Paleoclimatology. Wiley, New York, N.Y., pp. 199-224.

Broecker, W. S. and Peng, T. H., 1982. Tracers in the Sea. Eldigio Press, Palisades, New York, N.Y., 690 pp.

Burton, E. A., 1988. Laboratory investigation of the effects of seawater chemistry on carbonate mineralogy. Thesis. Washington Univ., St. Louis, 306 pp.

Burton, E. A. and Walter, L. M., 1988. Experimental investigation of $\mathrm{Mg} / \mathrm{Ca}$ and sulfate as controls on temporal variations in mineralogy of marine carbonates. Geol. Soc. Am. Abstr. with Programs, 20, p. 74.

Chow, N. and James, N. P., 1987. Facies-specific, calcitic 
and bimineralic ooids from Middle and Upper Cambrian platform carbonates, western Newfoundland, Canada. J. Sediment. Petrol., 57: 907-921.

Cooke, R. C. and Kepkay, P. E., 1984. Apparent calcite supersaturation at the ocean surface: Why the present solubility product of pure calcite in seawater does not predict the correct solubility of the salt in nature. Mar. Chem., 15: 59-69.

Culkin, F. and Cox, R. A., 1966. Sodium, potassium, magnesium, calcium and strontium in seawater. DeepSea Res., 13: 789-804.

Daetwyler, C. C. and Kidwell, A. L., 1959. The Gulf of Batabano, a modern carbonate basin. In: Fifth World Pet. Congr., 1., Pap., 1, pp. 1-20.

Davies, G. R., 1970. Carbonate bank sedimentation, eastern Shark bay, Western Australia. In: Carbonate Sedimentation and Environments, Shark Bay, Western Australia. Am. Assoc. Pet. Geol. Mem., 13: 85-168.

Davies, P. J. and Martin, K., 1976. Radial aragonite ooids, Lizard Island, Great Barrier Reef, Queensland, Australia. Geology, 4: 120-122.

Denham, C. R. and Scotese, C. R., 1988. Terra Mobilis - a plate tectonics program for the macintosh: v. 2.1. Earth in Motion Technol., Houston, Tex.

Douglas, J. G. and Williams, G. E., 1982. Southern Polar Forests: The early Cretaceous Floras of Victoria and their palaeoclimatic significance. Palaeogeogr., Palaeoclimatol., Palaeoecol., 39: 171-185.

DuToit, A. L., 1937. Our Wandering Continents. Oliver and Boyd, London, 366 pp.

Edmond, J. M. and Giesky, J. M. T. M., 1970. On the calculation of the degree of saturation of sea water with respect to calcium carbonate under in situ conditions. Geochim. Cosmochim. Acta, 34: 1261-1291.

Emery, K.O., 1968. Relict sediments on continental shelves of the world. Am. Assoc. Pet. Geol. Bull., 52: 445-464.

Fabricius, F. H., Berdau, D. and Munnich, K. O., 1970. Early Holocene ooids in modern littoral sands reworked from a coastal terrace, southern Tunisia. Science, 169: $757-760$.

Feelly, R. A., Byrne, R. H., Betzer, P. R., Gendron, J. F. and Acker, J. G., 1984. Factors influencing the degree of saturation of the surface and intermediate waters of the North pacific Ocean with respect to aragonite. J. Geophys. Res., 89: 10,631-10,640.

Fischer, A. G., 1981. Climate oscillations in the biosphere, in biotic crises. In: M. Nitecki (Editor), Ecological and Evolutionary Time. Academic Press, New York, N.Y., pp. 103-131.

Fischer, A. G., 1984. The two Phanerozoic supercycles. In: W. A. Berggren and J. A. Van Couvering (Editors), Catastrophes and Earth History - The New Uniformitarianism. Princeton Univ. Press, Princton, N.J., pp. 129-150.

Frakes, L. A and Francis, J. E., 1988. A guide to Phanerozoic cold polar climates from high-latitude icerafting in the Cretaceous. Nature, 333: 547-549.

Given, R. K. and Wilkinson, B. H., 1985. Kinetic control of morphology, composition, and mineralogy of abiotic sedimentary carbonates. J. Sediment. Petrol., 55: 109-119.
Irving, E. and Briden, J. C., 1962. Paleolatitude of evaporite deposits. Nature, 196: 425-428.

James, N. P. and Klappa, C. F., 1983. Petrogenesis of early Cambrian reef limestones, Labrador, Canada. J. Sediment. Petrol., 53: 1051-1096.

Keeling, C. D., 1968. Carbon dioxide in surface ocean waters - 4. Global distribution. J. Geophys. Res., 73: 4543-4553.

Koeppen W. and Wegener, A., 1924. Die Klimate der geologischen Vorzeit. Borntraeger, Berlin, pp. 255.

Land, L. S., Behrens, E. W. and Frishman, S. A., 1979. The ooids of Baffin Bay, Texas. J. Sediment. Petrol., 49: 1269-1278.

Leeder, M. R., 1982. Sedimentology: Process and Product. Allen and Unwin, Winchester, Mass, 344 pp.

Lees, A., 1975. Possible influence of salinity and temperature on modern shelf carbonate sedimentation. Mar. Geol., 19: 159-198.

Lightly, R. G., 1985. Preservation of internal reef porosity and diagenetic sealing of submerged early Holocene barrier reef, southeast Florida shelf. In: N. Schneider mann and P. M. Harris (Editors), Carbonate Cements. Soc. Econ. Paleontol. Mineral. Spec. Publ., 36: 123-153.

Loreau, J. P. and Purser, B. H., 1973. Distribution and ultrastructure of Holocene ooids in the Persian Gulf. In B. H. Purser (Editor), The Persian Gulf. Springer, New York, N.Y., $471 \mathrm{pp}$.

MacIntyre, W. G., 1965. The temperature variation of the solubility product of calcium carbonate in sea water. Fish. Res. Board Can., Ottawa, Rep., 200. 153 pp.

Mackenzie, F. T. and Pigott, J. D., 1981. Tectonic controls of Phanerozoic sedimentary rock cycling. J. Geol. Soc. Lond., 138: 183-196.

Major, R. P., Halley, R. B. and Lukas, K. J., 1988. Cathodoluminescent bimineralic ooids from the Pleistocene of the Florida continental shelf. Sedimentology, 35 : 843-855.

Marshall, J. F. and Davies, P. J., 1975. High-magnesium calcite ooids from the Great Barrier Reef. J. Sediment. Petrol., 45: 285-291.

Milliman, J. D., 1969. Carbonate sedimentation on four southwestern Caribbean atolls and its relation to the "oolite problem". Trans. Gulf Coast Assoc. Geol. Soc., 19: 195-206.

Milliman, J. D., 1974. Marine carbonates. In: J. D. Milliman, G. Mueller, and U. Foerstner (Editors), Recent Sedimentary Carbonates. Springer, New York, N.Y., 1, 375 pp.

Milliman, J. D. and Barretto, H. T., 1975. Relict magnesian calcite oolite and subsidence of the Amazon shelf. Sedimentology, 22: 137-145.

Morse, J. W., Mucci, A. and Millero, F. J., 1980. The solubility of aragonite in seawater of $35 \%$ salinity at $25^{\circ} \mathrm{C}$ and atmospheric pressure. Geochim. Cosmochim. Acta, 44: 85-94.

Mucci, A., 1983. The solubility of calcite and aragonite in seawater at various salinities, temperatures and 1 atmosphere total pressure. Am. J. Sci., 283: 780-799.

Mucci, A., Cancuel, R. and Zhong, S., 1989. the solubility of calcite and aragonite in sulfate-free seawater and the 
seeded growth kinetics and composition of the precipitates at $25^{\circ} \mathrm{C}$. Chem. Geol., 74: 309-320.

Neiburger, M., Edinger, J. G. and Bonner, W. D., 1982. Understanding Our Atmospheric Environment. Freeman, San Francisco, 2nd ed., pp. 453.

Opdyke, B. N. and Wilkinson, B. H., 1989. Surface area control of shallow cratonic to deep marine carbonate accumulation. Palaeoceanography, 3: 685-705.

Opdyke, N. D., 1959. The impact of paleomagnetism on palaeoclimatic studies. Int. J. Bioclimatol. Biometerol., 3 (4A): 1-11.

Opdyke, N. D., 1962. Paleoclimatology and continental drift. In: S. K. Runcorn (Editor), Continental Drift. Academic Press, New York, N.Y., pp. 41-65.

Plath, D. C. and Pytkowicz, R. M., 1980. The solubility of aragonite in seawater at $25.0^{\circ} \mathrm{C}$ and $32.62 \%$ salinity, Mar. Chem., 10: 3-7.

Parrish, J. T., 1982. Upwelling and petroleum source beds, with reference to Paleozoic. Bull. Am. Assoc. Pet. Geol., 66: $750-774$.

Parrish, J. T., 1985. Latitudinal distribution of land and shelf and absorbed solar radiation during the Phanerozoic, U.S. Geol. Surv. Open File Rep., 803-827, p. 1-21.

Richter, D. K., 1976. Gravitational meniscus cement in a Holocene oolite near Neapolis (South-Peloponnes, Greece). Neues Jahrb. Paläontol. Abh., 151: 192-223.

Sandberg, P. A., 1983. An oscillating trend in Phanerozoic non-skeletal carbonate mineralogy. Nature, 305: 19-22.

Sass, E., Weiler, Y. and Katz, A., 1971. Recent lagoonal oolites in the Gulf of Suez. In: Abstr. 8th Int. Sedimentol. Congr., Heidelberg, p. 87.

Sandberg, P. A., 1985. Nonskeletal aragonite and $\mathrm{CO}_{2}$ in the Phanerozoic and Proterozoic, In: E. T. Sundquist and W. S. Broecker (Editors), The Carbon Cycle and Atmospheric $\mathrm{CO}_{2}$ : Natural Variations Archean to Present (Am. Geophys. Union Monogr., 32). Am. Geophys. Union, Washington, D.C. pp. 585-594.

Schlager, W. and James, N. P., 1978. Low-magnesium calcite limestones forming at the deep-sea floor, Tongue of the Ocean, Bahamas. Sedimentology, 25: 675-702.

Scotese, C. R. and Barrett, S. F., 1989. Gondwana's movement over the South Pole during the Paleozoic: Evidence from lithologic indicators of climate. In: W. S. McKerrow and C. R. Scotese (Editors), Palaeozoic Palaeogeography and Biogeography. Geol. Soc. Lond. Mem., 12: 75-86.

Smiley, C. J., 1967. Paleoclimatic interpretations of some Mesozoic floral sequences. Am. Assoc. Pet. Geol. Bull., 51: 849-863.

Takahashi, T., Kaiteris, P., Broecker, W. S. and Bainbridge, A. E., 1976. An evaluation of the apparent dissociation constants of carbonic acid in seawater. Earth Planet. Sci. Lett., 32: 458-467.

Takahashi, T. and Azevedo, A. E. G., 1982. The oceans as a $\mathrm{CO}_{2}$ reservoir. In: Interpretation of Climate and Photo- chemical Models, Ozone and Temperature Measurements. Am. Inst. Phys., New York, N.Y., pp. 83-109.

Takahashi, T., Broecker, W. S., Bainbridge, A. E. and Weiss, R. F., 1980. Carbonate chemistry of the Atlantic, Pacific, and Indian Oceans - the results of the GEOSECS expeditions 1972-1978. Lamont-Doherty Geol. Obs. Tech. Rep., 1, CU-1-80, Palisades, N.Y., 211 pp.

Takahashi, T., Chipman, D. and Volk, T., 1982. Geographical, seasonal, and secular variations of the partial pressure of $\mathrm{CO}_{2}$ in surface waters of the North Atlantic Ocean - the results of the North Atlantic TTO program. Proc. Carbon Dioxide Res. Conf., Carbon Dioxide, Science and Consensus. Dep. Energy,. Washington, D.C., pp. 123-145.

Tucker, M. E., 1981. Sedimentary Petrology: An Introduction, In: A. Hallam (Editor), Geoscience Texts. Wiley, New York, N.Y., 3, p. 252.

Tucker, M. E., 1984. Calcitic, aragonitic and mixed aragonitic ooids from the mid-Proterozoic Belt Supergroup, Montana. Sedimentology, 31: 627-644.

Vail, P. R., Mitchum, R. M., Todd, R. G., Widmier, J. M., Thomson, S., Sangree, J. B., Bubb, J. N. and Hatleild, W. G., 1977. Seismic stratigraphy and global changes of sea level, In: C. E. Payton (Edior), Seismic Stratigraphy Applications to Hydrocarbon Exploration. Mem. Am. Assoc. Pet. Geol., 26: 49-212.

Van der Voo, R., 1988. Paleozoic paleogeography of North America, Gondwana, and intervening displaced terrains - comparisons of paleomagnetism with paleoclimatology and biogeographical patterns. Geol. Soc. Am. Bull., 100: 311-324.

Walter, L. M. and Morse, J. W., 1984. Magnesium calcite stabilities - a reevaluation. Geochim. Cosmochim. Acta, 48: 1059-1069.

Ward, W. C. and Brady, M. J., 1973. High-energy carbonates on the inner shelf, northeastern Yucatan Peninsula, Mexico. Trans. Gulf Coast Assoc. Geol. Soc., 23: 226-238.

Wegener, A., 1915. Die Entstehung der Kontinente und Ozeane, Vieweg, Braunschweig, pp. 94.

Wilson, J. L., 1975. Carbonate Facies in Geologic History. Springer, New York, N.Y., 471 pp.

Wolfe, J. A. and Upchurch Jr., G. R., 1987. North American nonmarine climates and vegetation during the Late Cretaceous. Palaeogeogr., Palaeoclimatol., Palaeoecol., 61: 33-77.

Worsley, T. R., Nance, R. D. and Moody, J. B., 1986. Tectonic cycles and the history of the Earth's biogeochemical and palaeoceanographic record. Palaeoceanography, 1: 233-263.

Zans, V. A., 1958. The Pedro Cays and Pedro Bank. Report on the survey of the cays, 1955-1957. Jamaican Geol. Surv. Dep. Bull., 3: 1-47.

Ziegler, A. M., Hulver, M. L., Lottes, A. L. and Schmachtenberg, W. F., 1984. Uniformitarianism and paleoclimates - inferences from the distribution of carbonate rocks. In: P. Brenchley (Editor), Fossils and Climate. Wiley, New York, N.Y., pp. 3-27. 